\title{
Empowerment and Microfinance: A socioeconomic study of female garment workers in Dhaka City
}

\author{
M. A. Rahman*, M. Khatun, Z. Tasnim and N. Islam \\ Department of Agricultural Finance, Bangladesh Agricultural University, Mymensingh-2202, Bangladesh \\ *E-mail: marahman2307@gmail.com
}

\begin{abstract}
This paper is an endeavor to depict the reasons for migration and involving with garments industry, adequacy, sources and utilization of credit, and empowerment of the female garments workers in a selected area of Dhaka City. Primary data were collected from 60 respondents in two categories such as: 30 helpers and 30 operators, randomly. Descriptive statistics such as percentage and arithmetic mean were applied to analyze the data and to describe socioeconomic characteristics of the respondents. Poverty, search for job and husbands' work in Dhaka, financial help to family, secure more income and assure basic needs were the main reasons for involving with garments industry. Average amount applied for loan was Tk. 5650.00 and average amount of loan received was Tk. 4450.00 which was $78.23 \%$ of total applied amount in the category of 'Helper'. On the other hand, average amount applied for Ioan was Tk. 10540.00 and average amount of loan received was Tk. 7670.00 which was $72.77 \%$ of total applied amount in the category of 'Operator'. About 94\% respondents (Helper) keep their earnings and spend independently; this figure was about $97 \%$ for operator. Level of income, human and social capital improved in both helper and operator categories but savings decreased $66.67 \%$ and $40 \%$ respectively. In the areas of decision making like food selection, treatment, visit to relatives, family planning all the cases vastly improved. This study recommended measures for improving the prevailing microfinance facilities, to a great extent, to achieve female workers' empowerment and satisfaction at the maximum level.
\end{abstract}

Keywords: Female garments workers, Empowerment, Microfinance, Migration

\section{Introduction}

The readymade garments (RMG) industry in Bangladesh is the success story of the modern manufacturing sector after independence. The readymade garments (RMG) industry accounts for $78 \%$ of country's export earning, contributes more than 10\% to Gross Domestic Product (GDP), employs 3.6 million people directly, $80 \%$ of women and the industry has created a platform for 2.8 million women to engage in new productive role in the society and empowering them, playing a lead role to alleviate poverty through skill development and employment generation. Around 20 million people are directly and indirectly depending on this sector for their immediate livelihoods, accelerating the industrial growth and employment through exports (BGMEA, 2009). Women make up the majority of workers in the RMG sector as a whole, with most recent estimates suggesting that up to 1.7 million women were employed in the sector at present (Ahmed, 2009). Throughout the last two decades, a significant portion of the national economy is contributed by the garment sector. Hence the role of women in the urban economy of Bangladesh is not negligible as a large number of women are working in this sector in Dhaka. About $83 \%$ of female workers of garment sector were migrants from rural to urban areas (BGMEA, 2009). These garment workers are young, unmarried, less educated, of rural origin and from very poor families and inexperienced in urban life. Women are still migrating to the urban areas especially in Dhaka city to get a job in garment industry.

In essence, women's empowerment is a multi-dimensional concept that embraces a wide range of factors such as social customs, cultures and mores, religion, caste, family type etc., which may not be amenable to any "objective" scale of measurement. Accordingly, women's empowerment is tentatively defined as the transformation of the power relations between men and women at the individual, household, society as well as the national levels (IUSSP, 1997). At the macro level, among other indicators, women's empowerment, or lack of it, is identified with gender inequality in employment, earnings, education, life expectancy, and female-male ratio in the population. Though they fail to capture the full connotation of the term, these indicators are frequently mentioned in the literature as the proxy or indirect indicators of women's empowerment (Joshi, 1999). At the household level, women's empowerment was equated with 
their involvement in decision making such as the decisions on fertility, children's education and healthcare, marriage, women's freedom of mobility and access to and control of resources that are interpreted as the direct indicators of empowerment. Despite the multidimensionality of the concept, these direct indicators are thought to be correlated regardless of locations as well as cultural and religious orientations (Jejeebhoy, 1998).

When we discuss about the financial solvency of the female garment workers, apart from a very small proportion of senior and mid management staffs, women constitute the overwhelming majority of garment industry employees and vulnerable to financial condition. Average monthly income of garment workers varies from Tk.2000 to Tk.4000 depending on skills and experience. Generally speaking, formal financial services (such as commercial banks) did not cater to the needs of the garment workers and they remain out of reach of formal financial services. Semi formal financial services (NGO-MFIs) are mainly concentrated in rural areas. Although targeted micro lending for the urban poor starred to gain momentum, garment workers still largely remain out of microfinance services. So, the researcher attempted to undertake the study with the following objectives:

i) to identify the reasons for migration and involving with Garments Industry;

ii) to analyze adequacy, sources and utilization of credit by the sample respondents; and

iii) to study the female garments workers empowerment.

\section{Materials and Methods}

A garment factory at Mirpur in Dhaka was selected purposively for this study. A sample of 60 respondents in two categories such as: 30 Helpers and 30 Operators were taken randomly in order to meet the objectives of the study. Primary data were collected personally from the respondents through a sample survey with the help of a structured and pre-tested interview schedule. In this study, quantitative method like a survey method was chosen in order to get a reasonably true picture of the entire population. The data were collected during the period from February to April, 2013. Tabular method was used for a substantial part of data analysis. Simple statistical techniques such as percentage and arithmetic mean or average were employed to analyze the data and to describe socioeconomic characteristics of the respondents. The methodology was purely descriptive and explanatory in nature.

\section{Results and Discussion}

\section{Reasons of migration}

Table 1 shows that several factors seem to be responsible for the rural urban migration. In this study, $36.67 \%$ of the respondents (Helper) were migrated for search of job. Thus, the first reason for migration from rural areas to Dhaka was search of job. The second important causes identified by the migrants were husbands' work in Dhaka (33.33\%). The third important factor was extreme poverty or insolvency which was $30 \%$. On the other hand, in operator category, majority of the respondents $(56.67 \%)$ were migrated for search of job. The second important causes identified by the migrants were husbands' work in Dhaka about $23.33 \%$. The third important factor was extreme poverty or insolvency that was $20 \%$.

Table 1. Reasons of migration

\begin{tabular}{|l|l|c|c|}
\hline Category & Reasons & Number of respondent & Percentage \\
\hline \multirow{3}{*}{ Helper } & Extreme poverty/insolvency & 09 & 30 \\
& Search of job & 11 & 36.67 \\
& Marriage/husbands' work in Dhaka & 10 & 33.33 \\
\hline Total & & $\mathbf{3 0}$ & $\mathbf{1 0 0}$ \\
\hline \multirow{3}{*}{ Operator } & Extreme poverty/insolvency & 06 & 20 \\
& Search of job & 17 & 56.67 \\
& Marriage/husbands' work in Dhaka & 07 & 23.33 \\
\hline \multicolumn{1}{|c|}{ Total } & & $\mathbf{3 0}$ & $\mathbf{1 0 0}$ \\
\hline
\end{tabular}

Source: Field Survey, 2013 


\section{Reasons for Involving with Garments Industry}

Table 2 shows that $43.34 \%$ of the respondents (Helper) entered into the garments industry to help their family financially. While $3.33 \%$ and $26.67 \%$ entered to uplift living standard and to secure more income; $23.33 \%$ entered to satisfy basic needs. On the other hand, $36.67 \%$ of the respondents (Operator) entered into the garments industry to help their family financially. While $20 \%$ and $23.63 \%$ entered to uplift living standard and to secure more income, $20 \%$ of them entered to satisfy basic needs.

Table 2. Reasons for Involving with Garments Industry

\begin{tabular}{|l|l|c|c|}
\hline Category & Reasons & Number of respondent & Percentage \\
\hline \multirow{4}{*}{ Helper } & To secure more income & 08 & 26.67 \\
& To help family financially & 13 & 43.34 \\
& To uplift living standard & 01 & 3.33 \\
& To become independent & 01 & 3.33 \\
& To satisfy basic needs & 07 & 23.33 \\
\hline Total & & $\mathbf{3 0}$ & $\mathbf{1 0 0}$ \\
\hline \multirow{3}{*}{ Operator } & To secure more income & 07 & 23.33 \\
& To help family financially & 11 & 36.67 \\
& To uplift living standard & 06 & 20 \\
\hline Total & To satisfy basic needs & 6 & $\mathbf{1 0 0}$ \\
\hline
\end{tabular}

Source: Field Survey, 2013

\section{Sources of borrowing}

From the Table 3 appears that helper and operator take loan from different sources because they have had very poor salary. We can see that about $33.33 \%$ of the respondents (Helper) received credit from shopkeepers, $30 \%$ from friends and relatives, $16.67 \%$ from co-operatives and $20 \%$ from different NGOs. Table 4 also reveals that $13.33 \%$ of the respondents (Operator) received credit from shopkeepers, $33.33 \%$ from friends and relatives, $23.34 \%$ from co-operatives and $30 \%$ from different NGOs.

Shopkeepers and friends or relatives were two easily accessible sources although the interest rate is not certain. When the garments women require a big amount of money, they were not able to get loan from the bank, as they need to keep a mortgage (household assets, jewelry etc, for borrowing a large amount of money. Garments women also took loan from various co-operatives and NGOs.

Table 3. Sources of credit

\begin{tabular}{|l|l|c|c|}
\hline Category & Sources of credit & Number of respondent & Percentage \\
\hline \multirow{3}{*}{ Helper } & Shopkeepers & 10 & 33.33 \\
& Friends/relative & 09 & 30 \\
& Co-operatives & 05 & 16.67 \\
& NGOs & 06 & 20 \\
\hline Total & & $\mathbf{3 0}$ & $\mathbf{1 0 0}$ \\
\hline \multirow{3}{*}{ Operator } & Shopkeepers & 4 & 13.33 \\
& Friends/relative & 10 & 33.33 \\
& Co-operatives & 07 & 23.34 \\
& NGOs & 09 & 30 \\
\hline Total & & $\mathbf{3 0}$ & $\mathbf{1 0 0}$ \\
\hline
\end{tabular}

Source: Field Survey, 2013 


\section{Adequacy of loan received}

Availability of loan was very essential for female garment workers. Table 4 shows that the adequacy of loan for the garments women in the study area was satisfactory. Table 3 reveals that average amount applied for loan in "Helper" category was Tk. 5650.00 and average amount of loan received was Tk. 4450.00 which was $78.23 \%$ of total applied amount. On the other hand, average amount applied for loan in "Operator" category was Tk. 10540.00 and average amount of loan received was Tk. 7670.00 which was $72.77 \%$ of total applied amount.

Table 4. Adequacy of loan

\begin{tabular}{|l|c|c|c|}
\hline Category & $\begin{array}{c}\text { Average amount applied } \\
\text { for loan(Tk.) }\end{array}$ & $\begin{array}{c}\text { Average amount } \\
\text { received loan (Tk.) }\end{array}$ & $\begin{array}{c}\text { Amount received in percentage } \\
\text { from applied loan }\end{array}$ \\
\hline Helper & 5650.00 & 4450.00 & 78.23 \\
\hline Operator & 10540.00 & 7670.00 & 72.77 \\
\hline
\end{tabular}

Source: Field Survey, 2013

\section{Utilization of loaned money by the garments workers}

Proper utilization of credit was a prerequisite to attain aims and targets of both credit disbursement and credit receipt as well as for growth of income. In this sub section, a thorough investigation had been made to see the patterns of loan utilization in which sampled borrower's spent their loaned money for different purposes, such as for their own health, children's health, education and other similar requirements.

The garments women were utilizing their loaned money on various purposes such as business, social ceremony, consumption, handicraft etc. Table 5 reveals that the use for consumption was the highest $33.33 \%$ for helper followed by house repair $23.33 \%$, business $16.67 \%$ and other purpose. This table also reveals that the use for consumption was the highest $(26.67 \%)$ for operator followed by social ceremony and emergency purpose (16.67\%), business (13.33\%) and other purposes. The highest amount used for consumption purpose indicates the poverty situation of the women in the garments sector.

Table 5. Utilization of loaned money

\begin{tabular}{|l|l|c|c|}
\hline Category & Utilization of loaned money & $\begin{array}{c}\text { Number of } \\
\text { respondent }\end{array}$ & Percentage \\
\hline \multirow{5}{*}{ Helper } & Business & 05 & 16.67 \\
& Social ceremony & 02 & 6.67 \\
& Consumption & 10 & 33.33 \\
& Medical(health) & 03 & 10 \\
& Emergency & 07 & 23.33 \\
& Education & 03 & 10 \\
\hline Total & & 30 & 13.33 \\
& Business & 04 & 16.67 \\
\multirow{5}{*}{ Operator } & Social ceremony & 05 & 16.67 \\
& Handicraft & 05 & 26.67 \\
& Consumption & 08 & 6.67 \\
& Medical(health) & 02 & 16.67 \\
\hline Total & Emergency & 05 & 3.33 \\
\hline
\end{tabular}

Source: Field Survey, 2013 


\section{Monthly income by length of service}

Monthly income was very essential for each person every body depended on it. For this reason, monthly income influences peoples' living standard. In garments sector employee's, monthly income depends on mainly their work experience and length of service. From Table 6 we can see that, the job length of $26.67 \%$ respondents was 1 year and they earned Tk. 3000- Tk.3500 (Helper). About 23.33\% of the respondent whose length of job was 2 years and earned Tk. 3000-Tk. 3500 per month. About $10 \%$ of the respondents (Operator) length of service was 4 years and earned Tk.7600-Tk.8000 per month.

Table 6. Monthly income by length of service

\begin{tabular}{|l|l|c|c|c|c|c|}
\hline Category & $\begin{array}{c}\text { Monthly income } \\
\text { (Tk.) }\end{array}$ & \multicolumn{3}{|c|}{ Length of service (year) } & Total \\
\cline { 2 - 7 } & $3000-3500$ & $08(26.67)$ & $07(23.33)$ & $\mathbf{3}$ & $\mathbf{4}$ & - \\
Helper & $3600-4000$ & $01(3.33)$ & $02(6.67)$ & - & - & 15 \\
& $4100-4500$ & $02(6.67)$ & $01(3.33)$ & $02(6.67)$ & - & 03 \\
& $4600-5000$ & $01(3.33)$ & $03(10)$ & $02(6.67)$ & $01(3.33)$ & 07 \\
\hline Total & & $\mathbf{1 2}$ & $\mathbf{1 3}$ & $\mathbf{0 4}$ & $\mathbf{0 1}$ & $\mathbf{3 0}$ \\
\hline & $3500-4500$ & $01(3.33)$ & $01(3.33)$ & $03(10)$ & $01(3.33)$ & 06 \\
Operator & $4600-5500$ & - & $02(6.67)$ & $01(3.33)$ & $02(6.67)$ & 05 \\
& $5600-6500$ & - & - & $01(3.33)$ & $03(10)$ & 04 \\
& $6600-7500$ & - & $01(3.33)$ & $03(10)$ & $04(13.34)$ & 08 \\
\hline Total & $7600-8000$ & - & $02(6.67)$ & $02(6.67)$ & $03(10)$ & 07 \\
\hline
\end{tabular}

Source: Field Survey, 2013.Figures within parentheses indicate percentages of total

\section{Controls over income of the respondents}

Control over income of female garment workers indicated the empowerment of them. Generally, women had very less control over income in patrimonial society in Bangladesh. But the scenery had changed for the female garment workers. Table 7 shows that $93.33 \%$ of respondents (Helper) kept their earnings and spent independently and this figure was $96.67 \%$ for Operator.

Table 7. Control over income of the respondents

\begin{tabular}{|l|l|c|c|}
\hline Category & Who keeps the earnings & Number of respondent & Percentage \\
\hline \multirow{5}{*}{ Helper } & Self & 28 & 93.33 \\
& Father & 2 & 6.67 \\
\cline { 2 - 4 } & Total & $\mathbf{3 0}$ & $\mathbf{1 0 0}$ \\
\cline { 2 - 4 } & Whether spend independently & 28 & \\
& Independently & 2 & 93.33 \\
& Not independently & $\mathbf{3 0}$ & $\mathbf{1 0 0}$ \\
\cline { 2 - 4 } & Total & 29 & 96.67 \\
\hline \multirow{5}{*}{ Operator } & Self & 01 & 3.33 \\
\cline { 2 - 4 } & Father & $\mathbf{3 0}$ & $\mathbf{1 0 0}$ \\
\cline { 2 - 4 } & Total & & 96.67 \\
\cline { 2 - 4 } & Whether spend independently & 29 & 3.33 \\
\hline & Independently & 01 & $\mathbf{1 0 0}$ \\
\hline
\end{tabular}

Source: Field Survey, 2013 


\section{Changes in the financial resources}

Another source of power to empower was financial resources. It was observed in Table 8 that $50 \%$ of the respondents improved their income. Only $10 \%$ of the respondents (Helper) expressed that income had decreased. In case of saving, $66.67 \%$ of the Helpers, and $40 \%$ of the Operators claimed that amount of their savings decreased. This situation was easily understandable because of living expenses had quite higher than their salary.

Table 8. Changes in the financial resources

\begin{tabular}{|l|c|c|c|c|}
\hline Category & \multirow{2}{*}{ Type } & \multicolumn{3}{|c|}{ Degree of change } \\
\cline { 3 - 5 } & & Improved & Unchanged & Decreased \\
\hline \multirow{3}{*}{ Helper } & Income & 15 & 12 & 03 \\
& & $(50)$ & $(40)$ & $(10)$ \\
& Savings & 00 & 10 & 20 \\
Operator & & - & $(33.33)$ & $(66.67)$ \\
& Income & 15 & 15 & 00 \\
& & $(50)$ & $(50)$ & - \\
& Savings & 05 & 13 & 12 \\
& & $(16.67)$ & $(43.33)$ & $(40)$ \\
\hline
\end{tabular}

Source: Field Survey, 2013. Figures within parentheses indicate percentages of total

\section{Changes in the human capital}

The stock of competencies, knowledge, social and personality attributes, including creativity, embodied in the ability to perform labour so as to produce economic value indicate the respondents' human capital. Table 9 shows that $66.67 \%$ of the Helpers improved mobile operating capacity and $36.67 \%$ improved their writing ability. On the other hand, those figures were $56.67 \%$ and $53.33 \%$ for the Operators.

Table 9. Changes in the human capital

\begin{tabular}{|l|l|c|c|}
\hline Category & \multicolumn{1}{|c|}{ Types } & \multicolumn{2}{|c|}{ Degree of change } \\
\cline { 3 - 4 } & Mobile operating capacity & Improved & Unchanged \\
\hline \multirow{3}{*}{ Helper } & Calculation/counting ability & $20(66.67)$ & $10(33.33)$ \\
& Signature ability & $21(16.67)$ & $25(83.33)$ \\
& Writing ability & $11(36.67)$ & $09(30)$ \\
& Mobile operating capacity & $17(56.67)$ & $19(63.33)$ \\
\hline \multirow{3}{*}{ Operator } & Calculation/counting ability & $07(23.33)$ & $13(43.33)$ \\
& Signature ability & $21(70)$ & $23(76.67)$ \\
& Writing ability & $16(53.33)$ & $09(30)$ \\
& &
\end{tabular}

Source: Field Survey, 2013.Figures within parentheses indicate percentages of total

\section{Changes in the social capital}

The quality and quantity of respondent's social interactions could be increased by the institutions, relationships and norms. Increasing evidence shows that social cohesion was critical for societies to prosper economically and for development to be sustainable. Social capital was not just the sum of the institutions which underpin a society - it was the glue that holds them together. Table 10 indicates that $36.67 \%$ of the respondents (both categories) improved their social prestige and $46.67 \%$ of the respondents (Operator) improved social networks. It happened mostly for interaction with different colleagues, friends and relatives. 
Rahman et al.

Table 10. Changes in the social capital

\begin{tabular}{|l|l|c|c|}
\hline Category & \multicolumn{1}{|c|}{ Types } & \multicolumn{2}{|c|}{ Degree of change } \\
\cline { 2 - 4 } & & Improved & Unchanged \\
\hline \multirow{4}{*}{ Helper } & Social networks & $12(40)$ & $18(60)$ \\
& Decision making ability & $10(33.33)$ & $20(66.67)$ \\
& Relationship with in-laws & $07(23.33)$ & $23(76.67)$ \\
& Social prestige & $11(36.67)$ & $19(63.33)$ \\
& Conflict resolution & $05(16.67)$ & $15(50)$ \\
\hline \multirow{4}{*}{ Operator } & Social networks & $14(46.67)$ & $16(53.33)$ \\
& Decision making ability & $21(70)$ & $09(30)$ \\
& Relationship with in-laws & $15(50)$ & $15(50)$ \\
& Social prestige & $11(36.67)$ & $19(63.33)$ \\
& Conflict resolution & $13(43.33)$ & $17(56.67)$ \\
\hline
\end{tabular}

Source: Field Survey, 2013. Figures within parentheses indicate percentages of total

\section{Scale of decision making}

Decision making power expressed the empowerment of the respondents in a family. Table 11 reveals that $66.67 \%$ of the respondents (Helper) improved their decision making power to food selection and $60 \%$ of the respondents (Helper) improved buying and selling, and family planning decision making opportunities. Those figures were $83.33 \%, 76.67 \%$, and $60 \%$ respectively, for the respondents of Operator category.

Table 11. Scale of decision making

\begin{tabular}{|l|l|c|c|}
\hline \multirow{1}{*}{ Category } & \multicolumn{1}{|c|}{ Types } & \multicolumn{2}{|c|}{ Degree of change } \\
\cline { 2 - 4 } & & Improved & Unchanged \\
\hline \multirow{5}{*}{ Helper } & Buying and selling & $18(60)$ & $12(40)$ \\
& Food selection & $20(66.67)$ & $10(33.33)$ \\
& Children's education & $15(50)$ & $15(50)$ \\
& Treatment & $17(56.67)$ & $13(43.33)$ \\
& Deposit & $05(16.67)$ & $25(83.33)$ \\
& Nursing & $07(23.33)$ & $23(76.67)$ \\
& Family planning & $18(60)$ & $12(40)$ \\
& Choice of work & $12(40)$ & $18(60)$ \\
& Visit to relatives & $17(56.67)$ & $13(43.33)$ \\
& Social and religious function & $19(63.33)$ & $11(35.67)$ \\
\hline \multirow{5}{*}{ Operator } & Buying and selling & $23(76.67)$ & $07(23.33)$ \\
& Food selection & $25(83.33)$ & $05(16.67)$ \\
& Children's education & $18(60)$ & $12(40)$ \\
& Treatment & $19(63.33)$ & $11(36.67)$ \\
& Deposit & $07(23.33)$ & $23(76.67)$ \\
& Nursing & $16(53.33)$ & $14(46.67)$ \\
& Family planning & $18(60)$ & $12(40)$ \\
& Choice of work & $15(50)$ & $15(50)$ \\
& Visit to relatives & $20(66.67)$ & $10(33.33)$ \\
& Social and religious function & $17(56.67)$ & $13(43.33)$ \\
\hline
\end{tabular}

Source: Field Survey, 2013. Figures within parentheses indicate percentages of total 


\section{Conclusion}

The garment sector has an incredible contribution to the Bangladesh economy and the lion's share of the contribution came from poor female garments workers who were basically migrated from rural areas. Due to participation in this income generating sector in the urban areas, their decision making power, life and status in the society got upgraded. However, largely, the condition of female garment workers was very frustrating. Even the level of income of the female garment workers' relatively higher than before but they had still been suffering financial shortages due to increased living cost in the urban areas. To meet-up the financial necessity, they were looking for loan from informal sources and formal microfinance institutions. Therefore, flexible savings and credit services for the garment workers, if made available at garment factory premises, could be of immense benefit for the female garment workers. Moreover, if garment owners allow to operating microfinance programme for its staff and workers from the office located at factory premises, it could drastically reduce overhead cost of financial transactions of the garments workers.

\section{References}

BGMEA. 2009. (Bangladesh Garment Manufacturers and Exporters Association) Member's Directory. Annual Report. Dhaka, Bangladesh. pp. 4-7.

Ahmed, N. 2009. 'Sustaining Ready-made Garment Exports from Bangladesh', Journal of Contemporary Asia, Vol. 39, No..4, pp. 597-618.

IUSSP (International Union for the Scientific Study of Population). 1997. Report on the Seminar on "Female Empowerment and Demographic Processes: Moving Beyond Cairo." Held at Lund University, Lund, April, pp. 21-24

Jejeebhoy, S.J. 1998. "Women's Autonomy in Rural India: Its Dimensions, Determinants and the Influence of the Context." In Women's Empowerment and Demographic Processes, eds. Harriet B. Presser and Gita Sen. Oxford: Oxford University Press.

Joshi, S.T. 1999. Women and Development - The Changing Scenario. New Delhi: Mitali Publications. 